\title{
Cibacron Blue F3GA ile modifiye polimerik mikroküreler ile RuBisCO adsorpsiyonu
}

\author{
Bilgen OSMAN ${ }^{1, *}$, Asuman CANSEV ${ }^{2}$ \\ ${ }^{1}$ Bursa Uludağ Üniversitesi, Fen-Edebiyat Fakültesi, Kimya Bölümü, Bursa \\ ${ }^{2}$ Bursa Uludağ Üniversitesi, Ziraat Fakültesi, Bahçe Bitkileri Bölümü, Bursa \\ Geliş Tarihi (Received Date): 18.01.2021 \\ Kabul Tarihi (Accepted Date): 09.03.2021
}

\section{$\ddot{\mathbf{O} z}$}

Bu çalışmada, Cibacron Blue F3GA (CB) ile modifiye edilmiş poli(hidrokisetil metakrilat) [PHEMA] mikroküreler hazırlandl ve ribuloz-1,5-bisfosfat karboksilaz/oksijenaz (RuBisCO) adsorpsiyonunda kullanıldi. PHEMA mikroküreler süspansiyon polimerizasyonu tekniği ile sentezlendi ve taramalı elektron mikroskopisi (SEM) ve Fourier transform infrared spektroskopisi (FTIR) ile karakterize edildi. CB ile kovalent olarak modifiye edilen CB-PHEMA mikroküreler RuBisCO adsorpsiyonunda kullanıldı. Adsorpsiyona CB içeriği, başlangıç RuBisCO derişimi (0,2-1.0 mg/mL), pH (5,5-9.0), sicaklık $\left(4^{\circ} \mathrm{C}, 22{ }^{\circ} \mathrm{C}\right.$ ve $\left.35^{\circ} \mathrm{C}\right)$ ve temas süresinin etkisi araştırıldi. $\mathrm{CB}-$ PHEMA mikrokürelerin $C B$ içeriği elementel analiz ile belirlenen $\% N$ miktart kullanılarak hesaplandı. CB-PHEMA mikrokürelere adsorplanan maksimum RuBisCO miktarl 33,59 mg/g olarak belirlendi $\left(22^{\circ} \mathrm{C}, \mathrm{pH}\right.$ 6,0). Ü f̧ farkl slcaklıkta $\left(4{ }^{\circ} \mathrm{C}, 22^{\circ} \mathrm{C}\right.$ ve $35^{\circ} \mathrm{C}$ ) elde edilen RuBisCO adsorpsiyon verilerinin izoterm ve kinetik modellere uygunluğu araştırıldı. RuBisCO adsorpsiyon verilerinin Freundlich izoterm modeli ve yalancl-ikinci derece kinetik modele uygun olduğu belirlendi. RuBisCO adsorpsiyonuna ilişkin Gibbs serbest enerji değişimi $\left(\Delta G^{\circ}\right)$ değerleri; $4{ }^{\circ} \mathrm{C}, 22{ }^{\circ} \mathrm{C}$ ve $35^{\circ} \mathrm{C}$ sicaklık için sirasiyla $-9,22 \mathrm{kj} / \mathrm{mol},-10,44 \mathrm{~kJ} / \mathrm{mol}$ ve $-11,33 \mathrm{~kJ} / \mathrm{mol}$ olarak hesaplandl. Entalpi değişimi $\left(\Delta H^{o}\right)+9,661 \mathrm{~kJ} / \mathrm{mol}$ ve entropi değişimi $\left(\Delta S^{\circ}\right)+68,14 \mathrm{~J} / \mathrm{mol} . \mathrm{K}$ olarak belirlendi. Termodinamik parametreler, CB-PHEMA mikrokürelere RuBisCO adsorpsiyonunun endotermik ve kendiliğinden gerçekleşen bir proses olduğunu kanttladi. CB-PHEMA mikrokürelerin ispanak protein ekstraktından RuBisCO adsorpsiyon performansı SDS-PAGE analizi ile değerlendirildi.

Anahtar kelimeler: RuBisCO, adsorpsiyon, Cibacron blue F3GA, bitki proteom analizi.

\footnotetext{
*Bilgen OSMAN, bilgeno@uludag.edu.tr, https://orcid.org/0000-0001-8406-149X Asuman CANSEV, auslu@uludag.edu.tr, https://orcid.org/0000-0002-3353-846X
} 


\title{
RuBisCO adsorption via polymeric microbeads modified with Cibacron Blue F3GA
}

\begin{abstract}
In this study, poly(hydroxyethyl methacrylate) [PHEMA] microbeads modified with Cibacron Blue F3GA (CB) were prepared and used for the adsorption of ribulose-1,5bisphosphate carboxylaseloxygenase (RuBisCO). PHEMA microbeads were synthesized by suspension polymerization and characterized by scanning electron microscopy (SEM) and Fourier transform infrared spectroscopy (FTIR). Then, CB modified CBPHEMA microbeads were used for RuBisCO adsorption. Effects of CB content, initial RuBisCO concentration (0.2-1.0 mg/mL), $\mathrm{pH}$ (5.5-9.0), temperature $\left(4{ }^{\circ} \mathrm{C}, 22{ }^{\circ} \mathrm{C}\right.$ and $35^{\circ} \mathrm{C}$ ) and contact time were investigated. The $C B$ amount of the CB-PHEMA microbeads was calculated via N\% determined by elemental analysis. The maximum RuBisCO amount adsorbed onto the CB-PHEMA microbeads was determined as 33.59 $\mathrm{mg} / \mathrm{g}\left(22{ }^{\circ} \mathrm{C}, \mathrm{pH}\right.$ 6.0). The RuBisCO adsorption data obtained at three different temperatures $\left(4^{\circ} \mathrm{C}, 22{ }^{\circ} \mathrm{C}\right.$ and $\left.35^{\circ} \mathrm{C}\right)$ were applied to isotherm and kinetic models. Freudlich isotherm model and pseudo-second order kinetic model were well fitted to adsorption data with high correlation coefficients. Gibss free energy changes $\left(\Delta G^{\circ}\right)$ of RuBisCO adsorption for $4{ }^{\circ} \mathrm{C}, 22{ }^{\circ} \mathrm{C}$ and $35^{\circ} \mathrm{C}$ were calculated as $-9.22 \mathrm{kj} / \mathrm{mol}$, -10.44 $\mathrm{kJ} / \mathrm{mol}$ and $-11.33 \mathrm{~kJ} / \mathrm{mol}$, respectively. Enthalpy change $\left(\Delta \mathrm{H}^{\circ}\right)$ was $+9.661 \mathrm{~kJ} / \mathrm{mol}$ and entrophy change $\left(\Delta S^{\circ}\right)$ was $+68.14 \mathrm{~J} / \mathrm{mol} . \mathrm{K}$. The calculated thermodynamic parameters showed that RuBisCO adsorption onto CB-PHEMA microbeads was endothermic and spontaneous. The RuBisCO adsorption performance of CB-PHEMA microbeads from spinach protein extract was evaluated by SDS-PAGE analysis.
\end{abstract}

Keywords: RuBisCO, adsorption, Cibacron blue F3GA, plant proteomics.

\section{Giriş}

Proteom analizi; bitkilerdeki gelişimsel değişmelerin, biyotik ve abiyotik stresin etkilerinin, hormonların rolünün belirlenmesi gibi araştırmalarda farklılaşan proteinlerin tespitinde kullanılır. Günümüzde iki boyutlu (2D) jel elektroforezi bitkilerin kompleks proteomlarının analizinde sıklıkla tercih edilen bir yöntemdir [1]. Bitkilerde proteom analizi; model bitki türleri, organeller ve stress fizyolojisi, üreme ve sinyal gibi bitki yaşam döngüsü ile ilgili spesifik olaylara 1şık tutmaktadır. Ancak, 2D jel elektroforezi ile bitki proteinlerinin ayrılmasında ve protein spotlarının belirlenmesinde biyolojik örneklerde bulunan yüksek bolluklu proteinlerin interferans etki yaptığ 1 rapor edilmektedir [2]. Proteom analizinde bitki dokuları ile insan dokuları karşılaştırıldığında bitki dokuları ile ilgili ilave problemlerin olduğu görülmektedir. İlk olarak, farklılaşmış bitki hücrelerinde büyük vakuoller ve rijid hücre duvarları nedeniyle çözünür protein miktarı düşüktür [3]. Ayrıca bitki hücreleri proteaz enzimlerince zengindir ve bu nedenle ekstraksiyon prosedürleri özel önlemler gerektirebilmektedir [4]. Polisakkaritler, lipidler, polifenoller ve ikincil metabolitler gibi bitkilere özgü hücresel bileşenler de proteinlerin ayrılmasında ve analizinde girişim etkisi yapmaktadır [5]. Bu alandaki temel zorluklar proteinlerin fizikokimyasal özelliklerindeki heterojenite ve protein derişimlerindeki farklılıklardır [6]. Kaynağa bağlı olarak, bitki proteomundaki dinamik aralık $10^{7}-10^{12}$ kadardır ve günümüzdeki protemik platformlar ile sadece küçük 
bir dinamik aralıktaki proteinler aynı anda analiz edilebilmektedir [7]. Bitki türüne bağlı olarak, toplam yaprak proteinlerinin yaklaşık \% 30-60'inı oluşturan ribuloz-1,5-bisfosfat karboksilaz/oksijenaz ( $\mathrm{RuBisCO}$ ), bitki proteom çalışmalarında tüm 2D jellerde en sık tanımlanan proteindir ve düşük bolluklu proteinlerin görüntülenmesini engellemektedir [8]. Yüksek bolluklu RuBisCO proteininin varlığ 1 , 2D jelde yalnızca düşük bolluktaki proteinlerin dinamik çözünürlüğünü ve verimini sınırlamakla kalmayıp aynı zamanda komşu protein türlerinin elektroforetik göçünü de etkilemektedir. Bu nedenle proteom analizi öncesi RuBisCO'nun uzaklaştırılması, proteom analizinde düşük derişimli proteinlerin belirlenmesi açısından son derece önemlidir. $\mathrm{RuBisCO}$ proteininin varlığından kaynaklanan girişim etkisi ile ilgili problem bugüne kadar çok az sayıda araştırmacı tarafından ele alınmıştır. RuBisCO proteininin proteomdan uzaklaştırılması için birçok çalışmada sıklıkla PEG (polietilen glikol) ile çöktürme [9,10] ve RuBisCO proteinine özgü IgY anti-RuBisCO içeren afinite kolonların kullanılması gibi yaklaşımlardan yararlanılmaktadır [11]. IgY anti-RuBisCO içeren afinite kolonların avantajı kolonun RuBisCO proteini için seçiciliğinin yüksek olmasıdır. Fakat afinite kolonları maliyetlidir ve aynı zamanda $\operatorname{IgY}$ anti-RuBisCO biyolojik bir ligand olduğundan raf ömrü kısa, üretilmesi oldukça zor ve kararsızdır.

Boya ligandları farklı türdeki proteinlere, özellikle enzimlere bazı durumlarda oldukça spesifik bir şekilde bağlanabilmektedir. Ayrıca boya ligandları ticari olarak üretilmektedir, ucuzdur ve özellikle hidroksil grubu içeren adsorbanlara kolayca immobilize edilebilmektedir. Boya ligandları sentetik olmalarına karşın, birçok proteinin aktif bölgesi ile proteinin substratlarını, kofaktörlerini ya da bağlanma ajanlarını taklit ederek etkileştikleri için afinite ligandı olarak adlandırılırlar. Reaktif boyalar olarak adlandırılan çok sayıda tekstil boyası, boya ligand afinite sistemlerinde proteinlerin ayrılması için kullanılır. Reaktif boyaların büyük bir çoğunluğu genellikle mono- yada diklorotriazin halkasına bağlı bir kromofor (azo boyaları, antrakinon ya da fitalosiyanin) içerir [12]. Boya ligand afinite, reaktif boyaların proteinlere seçici ve geri dönüşümlü bir şekilde bağlanabilme özelliğine dayanır [12,13]. Cibacron Blue F3GA (CB) boya ligandı ilk kez Sefadeks G-200 üzerine immobilize edilerek mayadan piruvat kinazın saflaştırılmasında kullanılmıştır [14]. Daha sonra bu yaklaşım, CB immobilize edilmiş farklı adsorbanların kullanılması ile çok sayıda proteinin saflaştırılmasında kullanılmıştır $[15,16,17]$. Birçok boya ligandının, özellikle de CB ve analoglarının bazı oksidoredüktazlar, fosfokinazlar ve ATPazlar ile etkileşimleri araştırılmıştır $[18,19]$. Elde edilen sonuçlar, boya yapısındaki antrakinon ve benzen sülfonat halkalarının enzimlere bağlanmada önemli olduğunu göstermiştir. Yapılan çalışmalar boyaların kinazlar ve dehidrojenazlar gibi nükleotid kofaktörleri kullanan enzim ve proteinlere daha seçici bir şekilde bağlandığını göstermektedir. Ancak CB, insan serum albumin [20,21], lizozim [22] ve interferon [23] gibi dinükletid baglama bölgeleri olmayan proteinlere de yüksek bir afinite ile bağlanmaktadır. Boyaların proteinlere bağlanması elektrostatik ve hidrofobik etkileşimler ile ya da daha spesifik bir şekilde ligand bağlanma bölgeleri ile "psedoafinite" etkileşimleri aracılığı ile gerçekleşmektedir.

$\mathrm{Bu}$ çalışmada, CB boyasının ligand olarak kullanıldığg bir afinite materyalinin bitkilerde yüksek bolluklu protein olduğu bilinen RuBisCO adsorpsiyonundaki etkinliği araştırıldı. $\mathrm{Bu}$ amaçla, ilk olarak poli(hidroksietil metakrilat) [PHEMA] mikroküreler sentezlendi. PHEMA mikroküreler CB boya ligandının kovalent olarak bağlanmasıyla modifiye edilerek CB-PHEMA mikroküreler hazırlandı. Hazırlanan CB-PHEMA mikroküreler ile sulu çözeltiden $\mathrm{RuBisCO}$ adsorpsiyon çalışmaları yapıldı. RuBisCO adsorpsiyonuna boya ligand $(\mathrm{CB})$ miktarı, $\mathrm{pH}$, başlangıç RuBisCO derişimi, temas süresi ve sıcaklığın 
etkisi araştırıldı. İzotermal, kinetik ve termodinamik analizler ile adsorpsiyon olayının fizikokimyasal doğası aydınlatıldı. Ayrıca, hazırlanan CB-PHEMA mikrokürelerin RuBisCO adsorpsiyonundaki tekrar kullanılabilirliği incelendi. Maksimum adsorpsiyonun gerçekleştiği koşullarda, CB-PHEMA mikrokürelerin ıspanaktan elde protein karışımından RuBisCO uzaklaştırma etkinliği sodyum dodesil sülfat poliakrilamid jel elektroforezi (SDS-PAGE) tekniği ile belirlendi.

\section{Deneysel çalışmalar}

\subsection{Malzemeler}

Ispanak RuBisCO enzimi (EC 4.1.1.39) ve Cibacron Blue F3GA (CB) Sigma firmasindan temin edildi (St. Louis, USA). Hidroksietil metakrilat (HEMA) ve etilen glikol dimetakrilat (EGDMA) Fluka firmasından satın alındı. Azobisizobütironitril (AIBN) Merck firmasından temin edildi. Askorbik asit, aseton, gliserol, hidroklorik asit, izopropanol, polivinilpolipirolidon (PVPP), fenilmetilsülfonil florür (PMSF), $\beta$ merkaptoetanol, sodyum tetraborat, triklorasestik asit (TCA), Trizma ${ }^{\circledR}$ baz, Trizma ${ }^{\circledR}$ hidroklorür ve Brillant blue G Sigma firmasından temin edildi (St. Louis, USA). Protein boyası, sığır serum albumin (BSA), sodyum dodesil sülfat (SDS), akrilamid/bis29:1, amonyum persülfat (APS), tetrametiletilendiamin (TEMED), SDS-PAGE molekül ağırlığ1 standartları ve Tris/Glisin/SDS tamponu Bio-Rad firmasından satın alındı (California,USA). Deneylerde kullanılan ultra saf su Elga Flex3 (Veloia Water Solutions \& Technologies, France) saf su cihazı ile hazırlandı.

\subsection{PHEMA mikrokürelerin sentezi ve karakterizasyonu}

PHEMA mikroküreler süspansiyon polimerizasyonu tekniği ile sentezlendi [22]. Dispersiyon fazı, $50 \mathrm{~mL}$ saf su içerisinde $0,2 \mathrm{~g}$ polivinilalkolün (PVA) çözünmesi ile hazırland. Organik fazın hazırlanması için; HEMA $(4 \mathrm{~mL})$ ve çapraz bağlayıcı EGDMA (4 mL), $8 \mathrm{~mL}$ toluen içerisinde çözüldü ve $0,1 \mathrm{~g}$ AIBN (başlatıcı) karışımın içerisine ilave edildi. Organik faz, sulu faz içerisinde dağıtılarak $400 \mathrm{rpm}$ karıştırma hızında polimerizasyon reaktöründe karıştırıldı. Polimerizasyon karışımı reaktör içerisinde $65{ }^{\circ} \mathrm{C}$ 'de 4 saat ve $80{ }^{\circ} \mathrm{C}$ ' de 2 saat süre ile polimerleştirildi. Elde edilen PHEMA mikroküreler, etil alkol ve saf su ile yıkanarak reaksiyona girmeyen monomerler uzaklaştırıldı. Elde edilen mikroküreler vakum etüvünde $50{ }^{\circ} \mathrm{C}$ 'de kurutuldu. Optik profilometre (Zeta Instruments) analizleri ile PHEMA mikrokürelerin düzgün küreler şeklinde olduğu tespit edildi. PHEMA mikroküreler 53-106 $\mu \mathrm{m}$ çap aralığında elenerek daha sonraki çalışmalarda kullanıldı. Mikrokürelerin kimyasal yapı analizi için Fourier transform infrared spektroskopisi (FTIR) (Perkin Elmer, Spectrum 100, USA) ve morfolojik analizi için taramalı elektron mikroskopisi (SEM) (CARL ZEISS EVO 40) tekniği kullanıldı.

\subsection{CB-PHEMA mikrokürelerin hazırlanması}

4,0 g NaOH içeren $100 \mathrm{~mL} \mathrm{NaOH}$ çözeltisine CB boya ligandı eklendi. Ardından 3,0 g PHEMA mikroküre çözeltiye ilave edilerek $80{ }^{\circ} \mathrm{C}$ sıcaklıkta çalkalamalı su banyosunda 4 saat karıştırıldı [22]. CB boya ligandı ile modifiye edilen PHEMA mikroküreler santrifüjlenerek (5000 rpm, 15 dakika) ortamdan ayrıldı ve etanol ve saf su ile yıkandı. Uygulanan yöntemde; $\mathrm{CB}$ derişimi $0,5-5,0 \mathrm{mg} / \mathrm{mL}$ aralığında değiştirilerek farklı $\mathrm{CB}$ içeriklerine sahip yedi farklı CB-PHEMA mikroküre hazırlandı. Hazırlanan CBPHEMA mikroküreler $50{ }^{\circ} \mathrm{C}$ sicaklikta etüvde kurutuldu. CB-PHEMA mikrokürelerin $\% \mathrm{~N}$ içeriği elementel analiz ile belirlendi (Leco, CHNS-932, USA). \%N miktarları 
kullanılarak PHEMA mikrokürelere bağlanan $\mathrm{CB}$ miktarları mg $\mathrm{CB} / \mathrm{g}$ mikroküre olarak hesapland1.

\subsection{RuBisCO adsorpsiyonuna $C B$ miktarının etkisi}

Farklı CB içeriklerine sahip CB-PHEMA mikroküreler RuBisCO adsorpsiyonu için

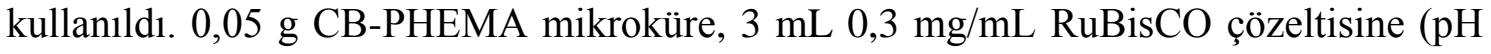
8,0, 0,1 M fosfat tamponu) ilave edilerek $200 \mathrm{rpm}$ karıştırma hızında oda sicaklığında 24 saat karıştırıldı. PHEMA mikroküreler de aynı koşullar altında RuBisCO adsorpsiyonunda kullanıldı. Adsorpsiyon öncesi ve sonrası RuBisCO çözeltilerindeki protein miktarı $280 \mathrm{~nm}$ dalga boyunda absorbans ölçümleri ile UV spektrofotometre (Shimadzu, UV-1700) ile belirlendi. CB-PHEMA mikroküreler üzerine adsorplanan RuBisCO miktarı Eşitlik (1) kullanılarak hesaplandı.

$Q=\frac{\left[\left(C_{o}-C\right) V\right]}{m}$

Eşitlik (1)'de; Q mikroküreler üzerine adsorplanan RuBisCO miktarı (mg RuBisCO/g mikroküre), $C_{0}$ ve C sırasıyla adsorpsiyon öncesi ve sonrası çözeltideki RuBisCO derişimi $(\mathrm{mg} / \mathrm{mL})$, V çözeltinin hacmi $(\mathrm{mL})$ ve $\mathrm{m}$ mikroküre miktarıdır $(\mathrm{g})$.

\section{5. pH etkisi}

RuBisCO adsorpsiyonuna $\mathrm{pH}$ etkisinin araştırılması için, $\mathrm{pH} 5,5$ ile 9,0 aralığında $0,1 \mathrm{M}$ fosfat tamponları (PB) kullanılarak hazırlanan RuBisCO çözeltileri (3 mL, 0,15 mg/mL) 0,05 g CB-PHEMA mikroküre ile oda sıcaklığında 24 saat inkübe edildi (Karıştırma hızı: 200 rpm). Farklı pH değerlerine sahip RuBisCO çözeltilerinden adsorplanan RuBisCO miktarı Eşitlik (1) kullanılarak hesaplandı.

\subsection{Başlangıç RuBisCO derişiminin etkisi}

RuBisCO adsorpsiyonuna başlangıç derişiminin etkisi $0,2 \mathrm{mg} / \mathrm{mL}-1,0 \mathrm{mg} / \mathrm{mL}$ RuBisCO derişim aralığında incelendi ( $\mathrm{pH}$ 6,0). Bu amaçla, 0,05 g CB-PHEMA mikroküre $3 \mathrm{~mL}$ RuBisCO çözeltisi ile oda sicaklığında 24 saat süre ile inkübe edildi. Adsorpsiyon çalışmaları üç farklı sıcaklıkta $\left(4^{\circ} \mathrm{C}, 22{ }^{\circ} \mathrm{C}\right.$ ve $\left.35^{\circ} \mathrm{C}\right)$ gerçekleştirildi. PHEMA mikroküreler ile RuBisCO adsorpsiyonu ise aynı RuBisCO derişim aralığında $(0,2$ $\mathrm{mg} / \mathrm{mL}-1,0 \mathrm{mg} / \mathrm{mL}) 22{ }^{\circ} \mathrm{C}$ 'de gerçekleştirildi. CB-PHEMA ve PHEMA mikroküreler üzerine adsorplanan RuBisCO miktarı Eşitlik (1) kullanılarak hesaplandı.

\subsection{Temas süresinin etkisi}

Temas süresinin adsorplanan RuBisCO miktarına etkisi üç farklı sıcaklıkta $\left(4^{\circ} \mathrm{C}, 22{ }^{\circ} \mathrm{C}\right.$ ve $\left.35^{\circ} \mathrm{C}\right)$ araştırıldı. Bu amaçla; $30 \mathrm{~mL}$ RuBisCO çözeltisi $(0,8 \mathrm{mg} / \mathrm{mL}, \mathrm{pH} 6,0), 0,5 \mathrm{~g}$ CB-PHEMA mikroküre ile inkübe edildi. 24 saat süre ile belirli zaman aralıklarında RuBisCO çözeltisinden örnek alındı. Örneklerdeki RuBisCO derişimi spektrofotometrik olarak belirlenerek CB-PHEMA mikroküreler üzerine adsorplanan RuBisCO miktarı hesaplandi.

\subsection{CB-PHEMA mikrokürelerin tekrar kullanılabilirliği}

CB-PHEMA mikrokürelerin RuBisCO adsorpsiyonundaki tekrar kullanılabilirliğini araştırmak için RuBisCO adsorpsiyon/desorpsiyon döngüsü 6 kez tekrarlandi. CBPHEMA mikroküreler $(0,05 \mathrm{~g}), 3 \mathrm{~mL}$ 0,4 mg/mL RuBisCO çözeltsi (pH 6,0) ile 24 saat inkübe edildi. Adsorpsiyon sonrası CB-PHEMA mikroküreler ortamdan ayrıldı ve 0,1 $\mathrm{M}$ fosfat tamponu ( $\mathrm{pH} 6,0)$ ile $3 \mathrm{kez}$ yıkand. Desorpsiyon $1 \mathrm{M}$ etilen glikol çözeltisi (3 
mL) kullanılarak gerçekleştirildi. Desorpsiyonun ardından mikroküreler fosfat tamponu (pH 6.0) ile yıkandı ve aynı koşullarda tekrar RuBisCO adsorpsiyonunda kullanıldı.

\subsection{SDS-PAGE analizi}

CB-PHEMA mikrokürelerin RuBisCO adsorpsiyonundaki etkinliği SDS-PAGE analizleri ile takip edildi. $\mathrm{Bu}$ amaçla; saf RuBisCO içeren çözeltiler ve 1spanak protein ekstraktı kullanıldı. Ispanak proteinlerinin ekstraksiyonu için uygulanan yöntemde; $1 \mathrm{mM}$ PMSF ve $1 \% \beta$-merkaptoetanol (w/v) içeren borat tamponu $(\mathrm{pH} 6,0)$ ekstraksiyon tamponu olarak kullanıldı. Ispanak örneği, ekstraksiyon tamponu ve PVPP; 1:3:0,35 oranında karıştırıldı. Hazırlanan homojenat 90 dakika süre ile $4{ }^{\circ} \mathrm{C}$ 'de santrifüjlendi (26.000 g, BeckmanCoulter, Allegra 64R). Süpernatan sirasiyla 0,45 $\mu \mathrm{m}$ ve 0,22 $\mu \mathrm{m}$ gözenek çapına sahip PVDF filtreden geçirildi. Taze hazırlanmış protein ekstraktı (3 $\mathrm{mL}, \mathrm{pH} 6,0)$ ve saf RuBisCO çözeltisi $(1 \mathrm{mg} / \mathrm{mL}, 3 \mathrm{~mL}, \mathrm{pH} 6,0), 4{ }^{\circ} \mathrm{C}$ sıcaklıkta 24 saat süre ile CB-PHEMA mikroküreler ile inkübe edildi. Ardından mikroküreler santrifüjlenerek ortamdan ayrıldı (5000 g, 30 dakika). CB-PHEMA ve PHEMA mikrokürelerin saf RuBisCO çözeltilerinden ve/veya 1spanak protein ekstraktından RuBisCO adsorpsiyon etkinliği SDS-PAGE ile dikey jel sistemi (Biorad, Miniprotean 3 Cell, USA) kullanılarak araştırıldı. Bu amaçla, adsorpsiyon öncesi ve sonrası saf RuBisCO çözeltilerinden ve ispanak protein ekstraktından alınan protein örnekleri SDSPAGE jellere yüklendi. Jele yüklenen örneklerdeki protein miktarı Bradford metodu ile belirlendi. Elektroforez işleminin ardından jeldeki proteinler \% $12(\mathrm{v} / \mathrm{v})$ TCA ile sabitlendi ve protein bantları Comassie Brillant Blue G-250 boyama ile görüntülendi.

\section{Sonuçlar ve tartışma}

\subsection{Mikrokürelerin kimyasal ve morfolojik özellikleri}

PHEMA mikrokürelerin morfolojisi SEM ile karakterize edildi. Elde edilen SEM fotografları uygulanan süspansiyon polimerizasyonu tekniği ile küresel formda PHEMA mikrokürelerin başarıyla sentezlendiğini kanıtladı (Şekil 1). SEM analizleri PHEMA mikrokürelerin pürüzlü bir yüzeye sahip olduğunu gösterdi. Yüzey pürüzlüğü, yüzey alanını arttırdığı için adsorpsiyon kapasitesini olumlu yönde etkileyen bir parametredir.

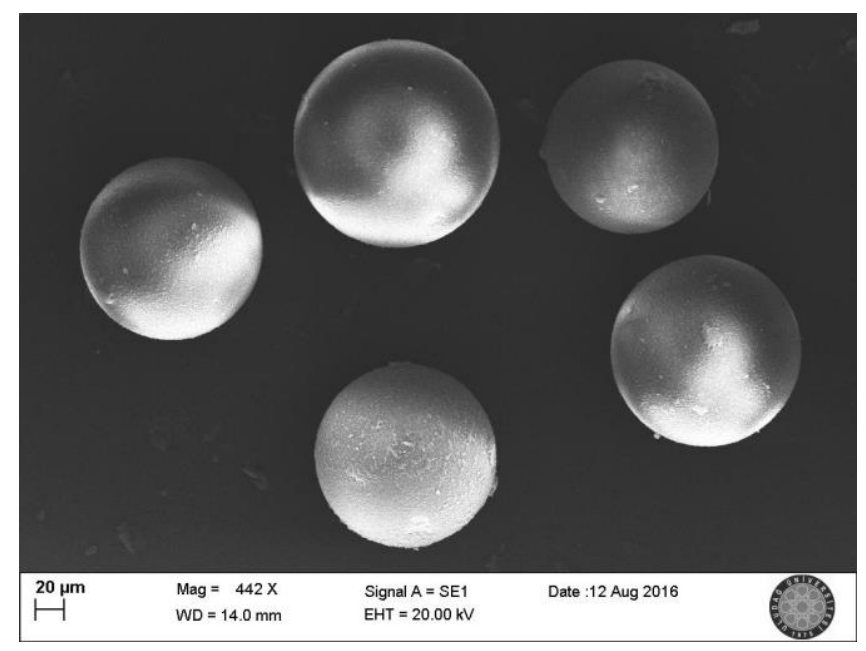

Şekil 1. PHEMA mikrokürelerin SEM fotografi. 
CB-PHEMA mikroküreler, CB moleküllerinin PHEMA mikrokürelere kovalent olarak bağlanması ile hazırlandı (Şekil 2). CB-PHEMA ve PHEMA mikrokürelerin kimyasal yapısı FTIR analizi ile belirlendi. PHEMA mikrokürelere ait FTIR spektrumunda; 1716 $\mathrm{cm}^{-1}$ ve $1146 \mathrm{~cm}^{-1}$ 'de sirasıyla $\mathrm{C}=\mathrm{O}$ ve $\mathrm{C}-\mathrm{O}$ (ester) gerilme titreşimlerine ait absorpsiyon bandları gözlemlendi. 3200-3600 $\mathrm{cm}^{-1}$ frekans aralığında gözlenen absorpsiyon bandı hidroksil gruplarına $(-\mathrm{OH})$ aittir. CB-PHEMA mikrokürelere ait FTIR spektrumunda $1022 \mathrm{~cm}^{-1}$ frekans değerinde ortaya çıkan absorpsiyon band, PHEMA mikrokürelere kovalent olarak bağlanan $\mathrm{CB}$ moleküllerindeki $\mathrm{S}=\mathrm{O}$ simetrik gerilme titreşimlerinden kaynaklandı. Ayrıca, $849 \mathrm{~cm}^{-1}$ and $897 \mathrm{~cm}^{-1}$ ' de sirasıyla CB molekülünün primer ve sekonder amin gruplarına ait absorpsiyon bandları gözlendi. CB-PHEMA mikrokürelere ait FTIR spektrumunda gözlenen ve CB molekülünün varlığından kaynaklanan absorpsiyon bandları kovalent modifikasyonun başarıyla gerçekleştiğini kanıtladı.

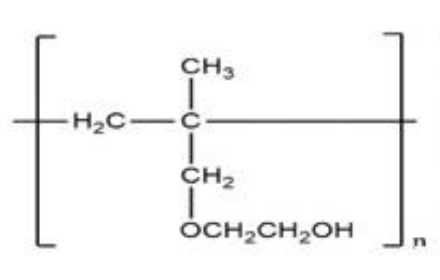

PHEMA mikroküreler

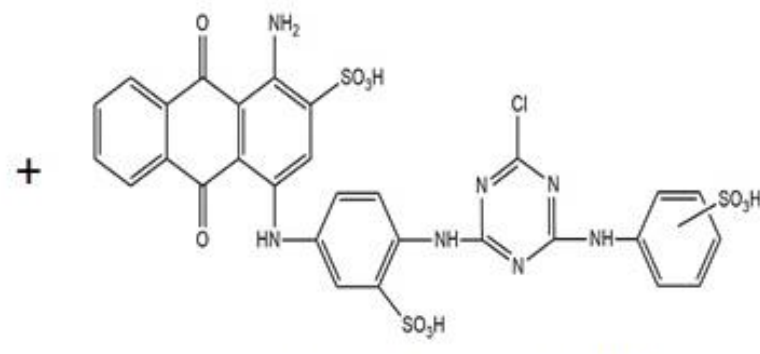

Cibacron Blue F3GA (CB)

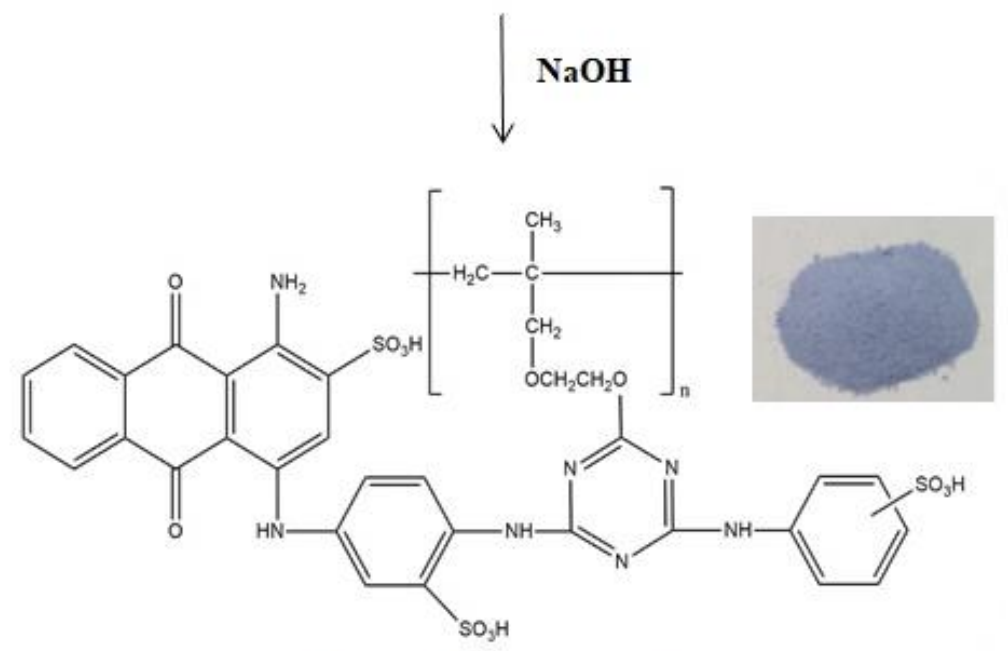

CB-PHEMA mikroküreler

Şekil 2. PHEMA mikrokürelerin CB ile modifikasyonunun şematik gösterimi.

PHEMA mikrokürelerin modifikasyonunda kullanılan $\mathrm{CB}$ çözeltisinin derişimi 0,5 ile $5,0 \mathrm{mg} / \mathrm{mL}$ aralığında değiştirilerek, değişen $\mathrm{CB}$ içeriklerine sahip yedi adet farklı CBPHEMA mikroküre hazırlandı. Mikrokürelerin CB içerikleri elementel analiz sonucu belirlenen $\% \mathrm{~N}$ miktarları kullanılarak hesaplandı ve CB-PHEMA mikroküreler sulu çözeltiden RuBisCO adsorpsiyonunda kullanıldı. CB-PHEMA mikrokürelerin CB içerikleri $8,75 \mathrm{mg} \mathrm{CB} / \mathrm{g}$ mikroküre $(0,5 \mathrm{mg} / \mathrm{mL}$ derişimde $\mathrm{CB}$ çözeltisi ile hazırlanan) ile $10,76 \mathrm{mg} / \mathrm{g}$ mikroküre $(5,0 \mathrm{mg} / \mathrm{mL}$ derişimde CB çözeltsi ile hazırlanan) aralığında değişti. Şekil 3'de CB içeriğinin CB-PHEMA mikrokürelerin RuBisCO adsorpsiyon kapasitesine etkisi gösterildi. Elde edilen sonuçlara göre; CB-PHEMA mikroküreler üzerine adsorplanan RuBisCO miktarı, artan $\mathrm{CB}$ içeriği ile arttı. Maksimum RuBisCO 
adsorpsiyonu 3,5 mg/mL derişiminde CB kullanılarak hazırlanan (10,44 mg CB /g mikroküre) CB-PHEMA mikroküreler ile elde edildi. Daha yüksek CB içeriğine sahip CB-PHEMA mikroküreler (10,76 mg $\mathrm{CB} / \mathrm{g}$ mikroküre) ile adsorplanan RuBisCO miktarı dikkate değer ölçüde azaldı. Bu sonuç; PHEMA mikrokürelerin yüzeyine immobilize edilen $\mathrm{CB}$ moleküllerinin miktarı arttıkça, $\mathrm{CB}$ moleküllerinin kendi aralarındaki etkileşimin de arttığını ve bu nedenle adsorplanan protein miktarının azalmış olabileceğini düşündürdü. RuBisCO adsorpsiyon çalışmaları için en yüksek RuBisCO adsorpsiyon kapasitesine sahip CB-PHEMA mikroküreler (10,44 mg CB / g polimer) kullanıldı.

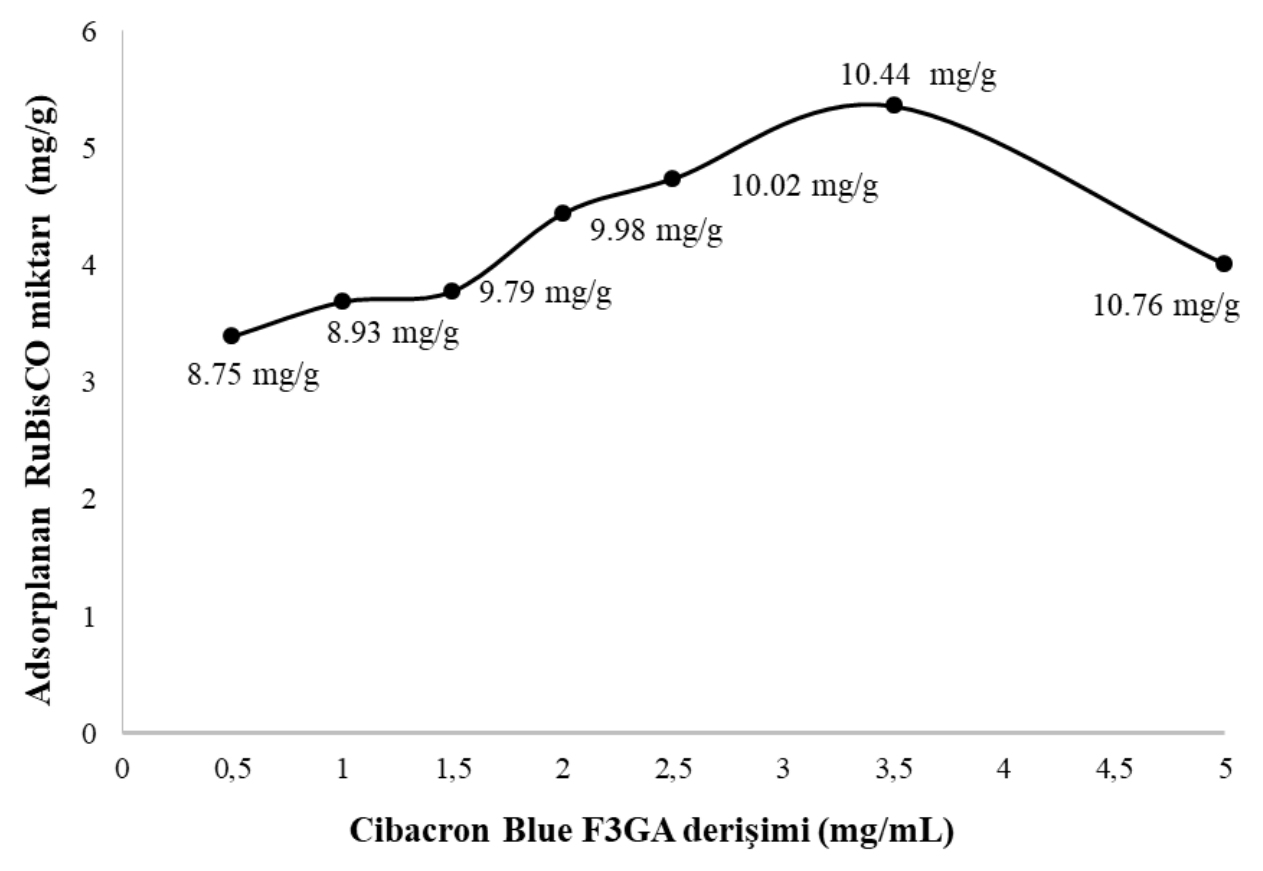

Şekil 3. CB içeriğinin CB-PHEMA mikroküreler üzerine RuBisCO adsorpsiyonuna etkisi (Başlangıç RuBisCO derişimi: 0,3 mg/mL; CB-PHEMA mikroküre miktarı: 0,05 $\mathrm{g}$; çözelti hacmi : $3 \mathrm{~mL}$; pH: 8,0; sicaklık : $22^{\circ} \mathrm{C}$; adsorpsiyon süresi : 24 saat).

\subsection{Adsorpsiyon çalışmaları pH etkisi}

Protein moleküllerinin ve/veya adsorbanın yükünü etkilediği için, ortamın $\mathrm{pH}$ değeri adsorpsiyon çalışmalarında önemli bir parametredir. RuBisCO proteini ve $\mathrm{CB}$ molekülü farklı $\mathrm{pH}$ değerlerinde farklı yükler taşımaktadır. Ortamın $\mathrm{pH}$ değerinin CB-PHEMA mikroküreler üzerine adsorplanan RuBisCO miktarına etkisi Şekil 4'te gösterildi. RuBisCO 5,5'ten daha küçük $\mathrm{pH}$ değerlerinde çözünür olmadığ 1 için, adsorpsiyon çalışmaları fosfat tamponları $(0,1 \mathrm{M})$ kullanılarak hazırlanan RuBisCO çözeltileri ile $\mathrm{pH}$ 5,5-9,0 aralığında gerçekleştirildi. Ayrıca RuBisCO çözeltilerine ( $\mathrm{pH}$ 5,5-9,0) derişimi $0,1 \mathrm{M}$ olacak şekilde $\mathrm{NaCl}$ eklenerek RuBisCO adsorpsiyonuna iyonik şiddetin etkisi araştırıldı. 


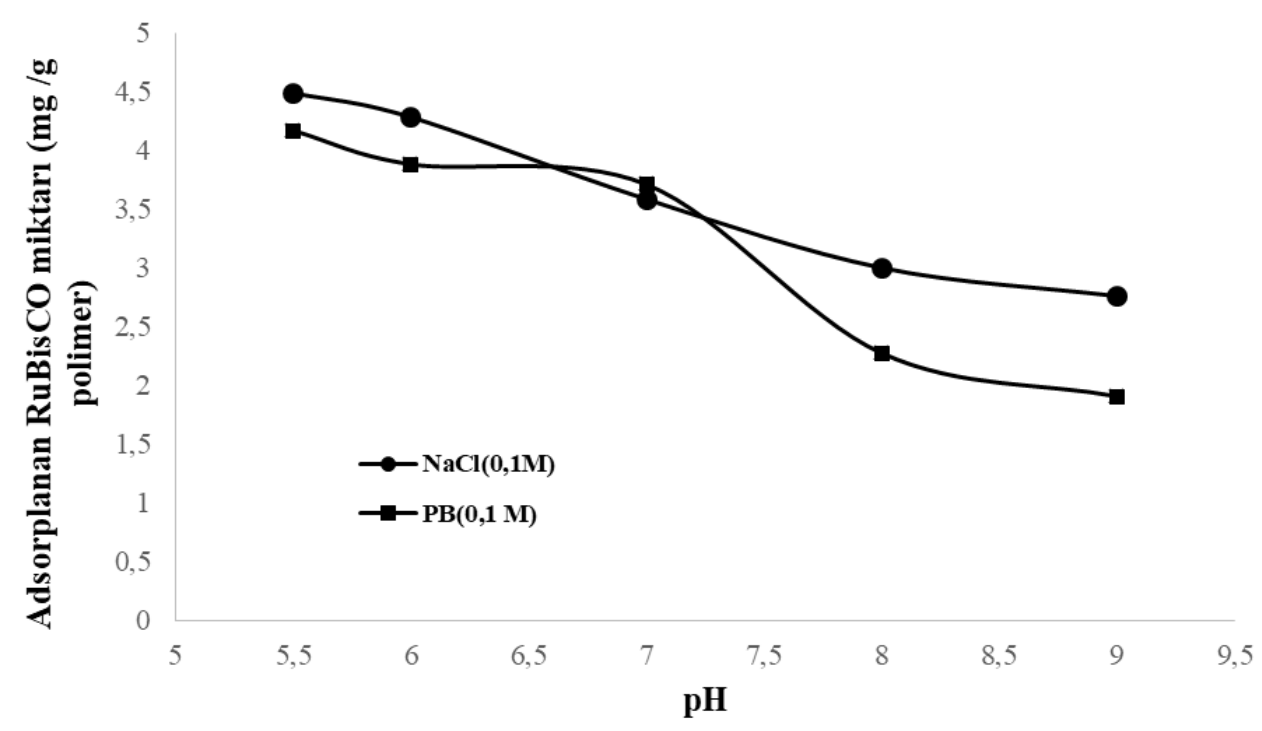

Şekil 4. pH değerinin CB-PHEMA mikroküreler üzerine RuBisCO adsorpsiyonuna etkisi (Başlangıç RuBisCO derişimi: 0,15 mg/mL; CB-PHEMA mikroküre miktarı: 0,05 $\mathrm{g}$; çözelti hacmi : $3 \mathrm{~mL}$, sıcaklık : $22^{\circ} \mathrm{C}$, adsorpsiyon süresi : 24 saat).

Şekil 4'te görüldüğü gibi ortamın $\mathrm{pH}$ değeri arttıkça adsorplanan RuBisCO miktarı dikkate değer ölçüde azaldı. RuBisCO'nun izoelektrik noktası (pI) 5,5-6,0'dır [24] ve izoelektrik noktada RuBisCO proteininin net yükü sıfırdır. 6,0'dan büyük $\mathrm{pH}$ değerlerinde ise RuBisCO net bir negatif yüke sahiptir. CB molekülleri de yapısında yer alan sülfonat grupları nedeniyle negatif yüke sahiptir. Dolayısıyla, $\mathrm{pH}$ 5,5 ile 9,0 arasında negatif yük taşıyan $\mathrm{CB}$ ve RuBisCO arasında elektrostatik bir itme söz konusudur. $\mathrm{Bu}$ nedenle, $\mathrm{pH}$ arttıkça $\mathrm{CB}$-PHEMA mikroküreler üzerine adsorplanan RuBisCO miktarının azaldığı düşünülmektedir. RuBisCO çözeltilerine $\mathrm{NaCl}$ ilave edilmesi ile tüm $\mathrm{pH}$ değerlerinde adsorplanan RuBisCO miktarında bir miktar artış gözlendi. $\mathrm{Bu}$ sonuç, $\mathrm{Na}^{+}$iyonlarının $\mathrm{CB}$ ve $\mathrm{RuBisCO}$ moleküllerinde bulunan negatif yüklü gruplara bağlanarak negatif yük yoğunluğunu azalttığını ve dolayısıyla elektrostatik itmenin azalması ile adsorplanan RuBisCO miktarının artmasına neden olduğunu düşündürdü. $\mathrm{Bu}$ koşullarda $\mathrm{CB}$ ve RuBisCO molekülleri arasında hidrofobik etkileşimler ve Van der Waals etkileşimlerinin daha etkin hale geleceği açıktır.

\section{Başlangıç RuBisCO derişiminin etkisi}

Başlangıç RuBisCO derişiminin CB-PHEMA mikrokürelere RuBisCO adsorpsiyonuna etkisi, $0,2 \mathrm{mg} / \mathrm{mL}-1,0 \mathrm{mg} / \mathrm{mL}$ RuBisCO derişim aralığında ve üç farklı sıcaklıkta $\left(4^{\circ} \mathrm{C}\right.$, $22{ }^{\circ} \mathrm{C}$ ve $35^{\circ} \mathrm{C}$ ) incelendi. Elde edilen sonuçlar Şekil 5 'te verildi. Başlangıç RuBisCO derişiminin artmasıyla adsorplanan RuBisCO miktarı arttı. 1,0 mg/mL (pH 6,0) başlangıç $\mathrm{RuBisCO}$ derişiminde $\mathrm{CB}$-PHEMA mikroküreler üzerine adsorplanan RuBisCO miktarı, $4{ }^{\circ} \mathrm{C}, 22{ }^{\circ} \mathrm{C}$ ve $35^{\circ} \mathrm{C}$ sicakl1klarda sirasiyla $28,79 \mathrm{mg} / \mathrm{g}, 33,59 \mathrm{mg} / \mathrm{g}$ ve $37,54 \mathrm{mg} / \mathrm{g}$ olarak belirlendi. 


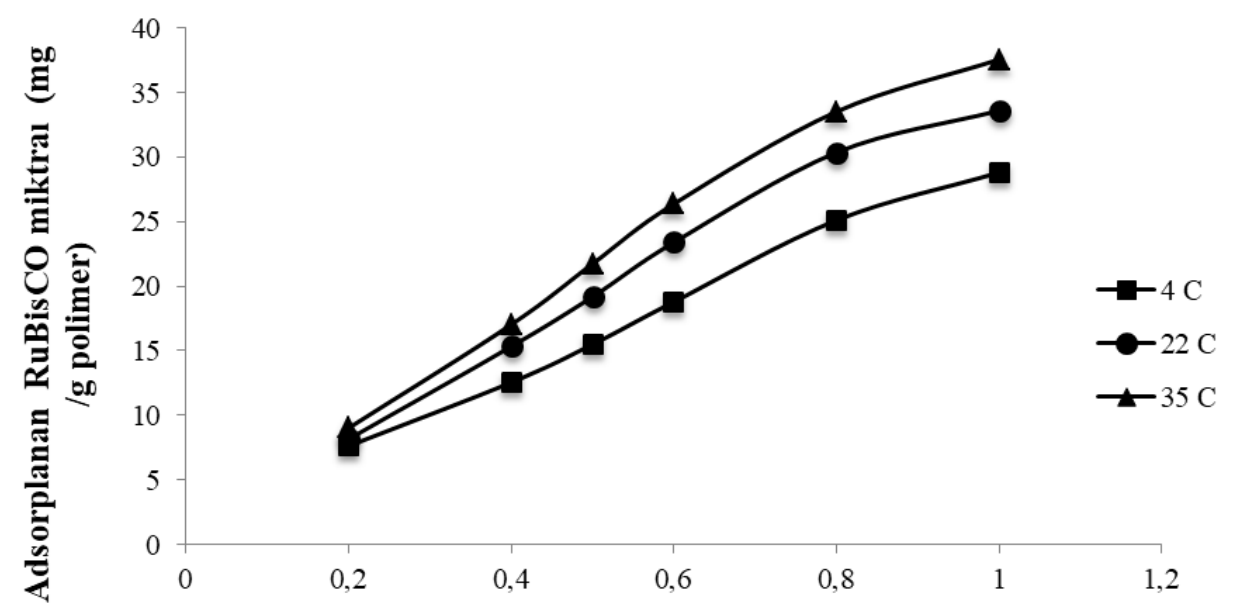

RuBisCO derişimi $(\mathrm{mg} / \mathrm{mL})$

Şekil 5. Başlangıç RuBisCO derişiminin CB-PHEMA mikroküreler üzerine RuBisCO adsorpsiyonuna etkisi (CB-PHEMA mikroküre miktarı: 0,05 g ; çözelti hacmi :3 mL, $\mathrm{pH}$ : 6,0, adsorpsiyon süresi : 24 saat).

PHEMA mikroküreler de aynı RuBisCO derişim aralığında $(0,2 \mathrm{mg} / \mathrm{mL}-1,0 \mathrm{mg} / \mathrm{mL})$ $22^{\circ} \mathrm{C}$ sicaklıkta RuBisCO adsorpsiyonu için kullanıldı. PHEMA mikroküreler üzerine adsorplanan RuBisCO miktarı belirlenerek, $22^{\circ} \mathrm{C}$ sıcaklıkta CB-PHEMA mikroküreler üzerine adsorplanan RuBisCO miktarı ile karşılaştırıldı (Şekil 6). 0,2 mg/mL ile 1,0 $\mathrm{mg} / \mathrm{mL}$ derişim aralığında PHEMA mikroküreler üzerine adsorplanan RuBisCO miktarı, tüm başlangıç derişimleri için CB-PHEMA mikroküreler üzerine adsorplanan RuBisCO miktarından düşüktür. $22^{\circ} \mathrm{C}$ sicaklıkta ve $1,0 \mathrm{mg} / \mathrm{mL}$ RuBisCO derişiminde adsorplanan RuBisCO miktarı, PHEMA ve CB-PHEMA mikroküreler için sırasıyla $13,65 \mathrm{mg} / \mathrm{g}$ ve $33,59 \mathrm{mg} / \mathrm{g}$ olarak belirlendi. $\mathrm{Bu}$ sonuç, $\mathrm{CB}$ ile RuBisCO proteini arasında elektrostatik etkileşimler, hidrojen bağları, Van der Waals etkileşimleri ve hidrofobik etkileşimlerin ortak etkisinden kaynaklanan spesifik bir etkileşim olduğunu açıkça kanıtladı.

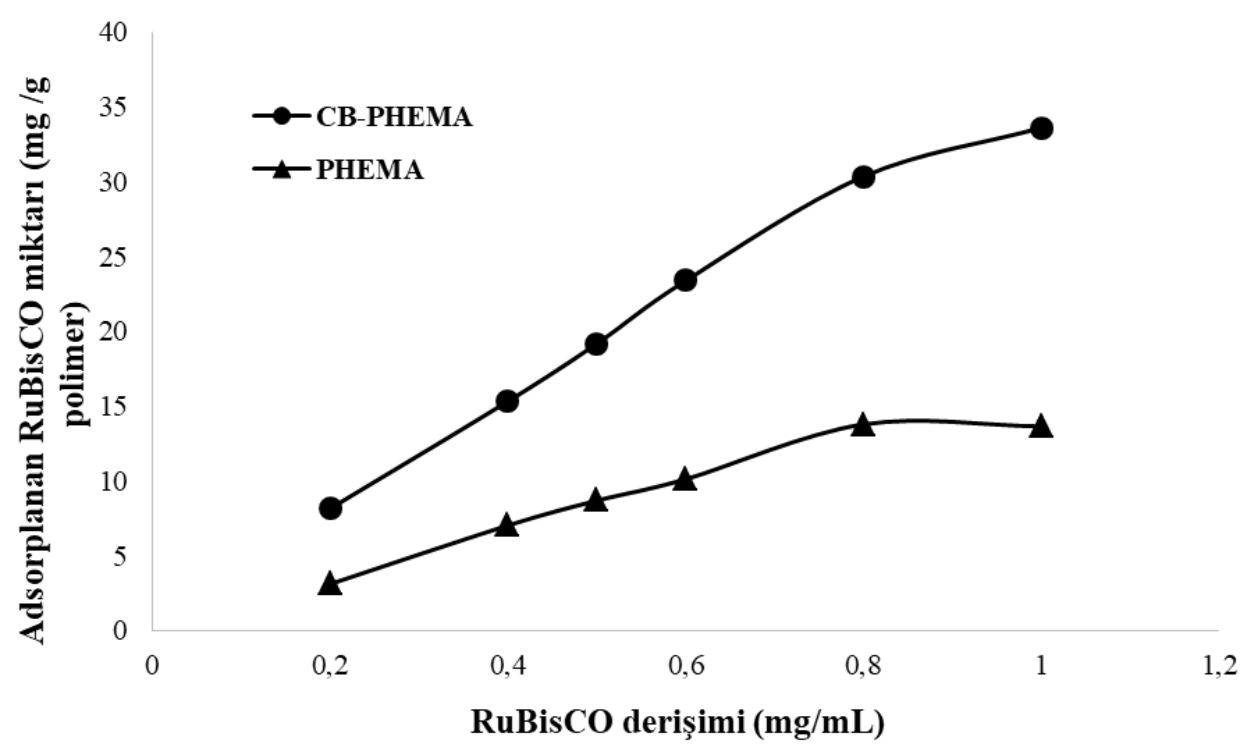

Şekil 6. Başlangıç RuBisCO derişiminin PHEMA ve CB-PHEMA mikroküreler üzerine RuBisCO adsorpsiyonuna etkisi (CB-PHEMA ve PHEMA mikroküre miktarı: 0,05 g ; çözelti hacmi :3 mL, pH: 6,0, sicaklık: $22^{\circ} \mathrm{C}$; adsorpsiyon süresi : 24 saat). 
Temas süresinin adsorplanan CB-PHEMA mikrokürelere adsorplanan RuBisCO miktarına etkisi üç farklı sıcaklıkta $\left(4^{\circ} \mathrm{C}, 22{ }^{\circ} \mathrm{C}\right.$ ve $\left.35^{\circ} \mathrm{C}\right)$ araştırıldı. Adsorplanan RuBisCO miktarı yaklaşık 180 dakikada denge değerine ulaştı (Şekil 7). Bu sonuç adsorpsiyonun oldukça hızlı gerçekleştiğini gösterdi. Adsorplanan $\mathrm{RuBisCO}$ miktarı yükselen sicaklık değeri ile arttı. Adsorplanan RuBisCO miktarı $4{ }^{\circ} \mathrm{C}, 22{ }^{\circ} \mathrm{C}$ ve $35^{\circ} \mathrm{C}$ sicaklık için sırasıyla $25,23 \mathrm{mg} / \mathrm{g}, 29,15 \mathrm{mg} / \mathrm{g}$ ve $32,35 \mathrm{mg} / \mathrm{g}$ olarak belirlendi. Elde edilen sonuçlar CB-PHEMA mikrokürelere RuBisCO adsorpsiyonunun endotermik olduğunu gösterdi.

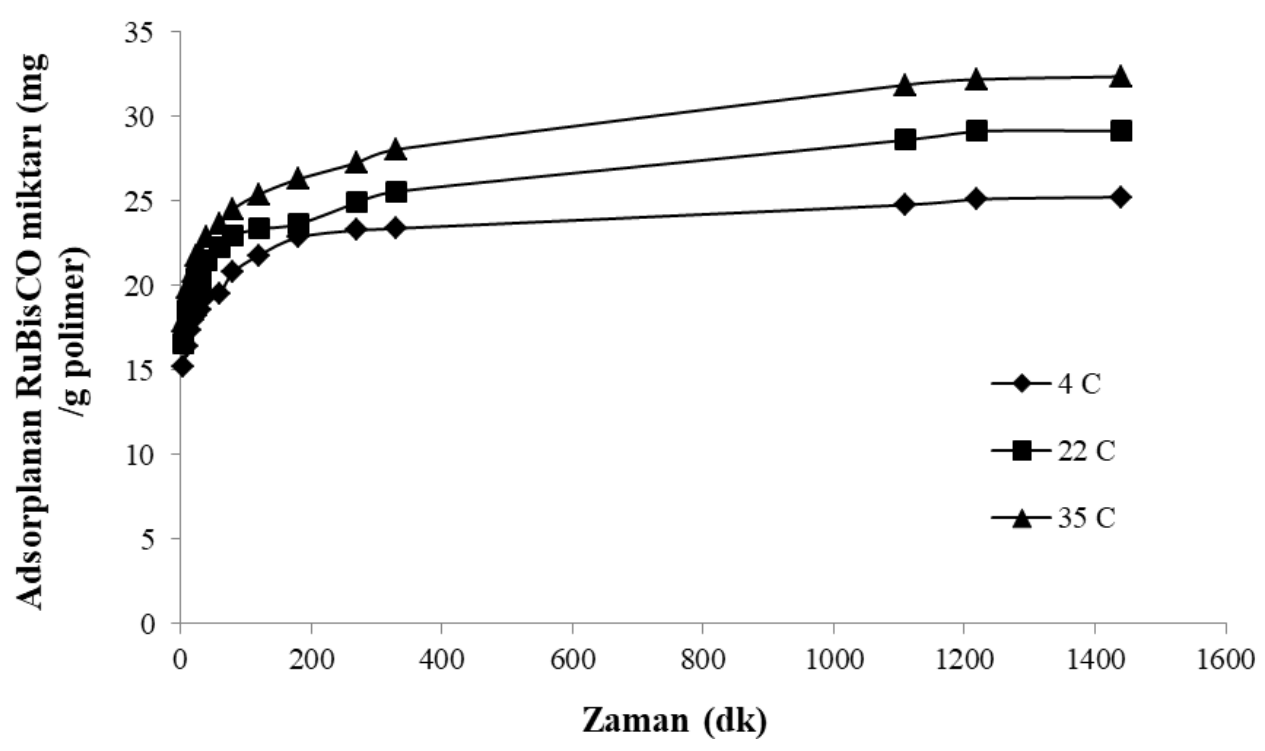

Şekil 7. Temas süresinin CB-PHEMA mikroküreler üzerine RuBisCO adsorpsiyonuna etkisi (Başlangıç RubisCO derişimi: 0,8 mg/mL, CB-PHEMA mikroküre miktarı: 0,5 g ; çözelti hacmi :30 mL, pH: 6,0, adsorpsiyon süresi : 24 saat).

\section{3. İotermal, kinetik ve termodinamik analizler}

Adsorpsiyon mekanizmasının aydınlatılmasında adsorpsiyon verilerinin kinetik ve izoterm modellere uygunluğunun araştırılması büyük bir öneme sahiptir. Kinetik, izoterm ve termodinamik parametrelerin belirlenmesi ile analit ve adsorban arasındaki etkileşimin kuvveti belirlenebilir. Ayrıca, entalpi değişimi $\left(\Delta H^{\circ}\right)$, entropi değişimi $\left(\Delta S^{\circ}\right)$, ve serbest enerji değişimi $\left(\Delta G^{\circ}\right)$ değerleri ile sırasıyla adsorpsiyon prosesinin doğası, adsorpsiyon sisteminin düzensizliği ve adsorpsiyonun kendiğinden gerçekleşebilirliği öngörülebilir. CB-PHEMA mikroküreler üzerine RuBisCO adsorpsiyonu için üç farklı sicaklıkta elde edilen adsorpsiyon verileri kullanılarak izotermal, kinetik ve termodinamik analizler yapıldı.

$0,2 \mathrm{mg} / \mathrm{mL}$ ile $1,0 \mathrm{mg} / \mathrm{mL}$ RuBisCO derişim aralığında üç farklı sıcaklıkta $\left(4{ }^{\circ} \mathrm{C}, 25^{\circ} \mathrm{C}\right.$ ve $35{ }^{\circ} \mathrm{C}$ ) elde edilen adsorpsiyon verilerinin Langmuir, Freundlich ve DubininRadushkevich (DR) izoterm modellerine uygunluğu araştırıldı. Langmuir izoterm modeline göre; adsorpsiyon tek tabakalı, adsorban yüzeyi homojen ve adsorban yüzeyindeki bağlanma bölgeleri eş enerjilidir. Langmuir izoterminin doğrusal denklemi Eşitlik (2)'deki gibidir [25]. 
$\frac{C_{e}}{q_{e}}=\frac{1}{Q_{L} K_{L}}+\frac{C_{e}}{Q_{L}}$

Eşitlik (2)'de; $C_{e}$ çözeltideki denge RuBisCO derişimini $(\mathrm{mg} / \mathrm{L}) ; q_{e}$ denge anında adsorplanan RuBisCO miktarını $(\mathrm{mg} / \mathrm{g}) ; Q_{L}$ yüzeydeki tek tabakalı adsorpsiyon için maksimum adsorpsiyon kapasitesini $(\mathrm{mg} / \mathrm{g})$ ve $K_{L}$ bağlanma bölgelerinin afinitesiyle ilgili Langmuir denge sabitini $(\mathrm{L} / \mathrm{mg})$ ifade etmektedir.

Freundlich izoterm modeli, heterojen bağlanma bölgeleri içeren adsorbanlarda adsorpsiyon prosesini açıklamak için kullanılmaktadır [26]. Freundlich izoterm modelinde bağlanma bölgeleri eş enerjili değildir. Ayrıca adsorbat molekülleri arasında etkileşim mümkündür. Freundlich izoterm modeli Eşitlik (3)'te verilen denklem ile ifade edilir.

$$
\ln q_{e}=\ln K_{f}+\frac{1}{n} \ln C_{e}
$$

Eşitlik (3)'te; $K_{f}$ Freundlich denge sabitini $\left[(\mathrm{mg} / \mathrm{g})(\mathrm{L} / \mathrm{mg})^{1 / \mathrm{n}}\right], C_{e}$ çözeltideki denge adsorbat derişimini $(\mathrm{mg} / \mathrm{L}), q_{e}$ denge anında adsorplanan adsorbat miktarını $(\mathrm{mg} / \mathrm{g})$ ve $n$ Freundlich sabitini (birimsiz) ifade etmektedir. Langmuir ve Freundlich izoterm modelleri sıklıkla kullanılmasına rağmen adsorpsiyon mekanizmasını açıklayamaz. Dubinin-Radushkevich (DR) izoterm modeli adsorpsiyon serbest enerjisini hesaplamak için kullanılır. DR izoterm modeline ait denklem Eşitlik (4) 'teki gibidir [27].

$\ln Q_{e}=\ln Q_{D R}-K_{D R} \varepsilon^{2}$

Eşitlik (4)'te; $Q_{e}$ g mikroküre başına adsorplanan mg RuBisCO miktarını (mg/g), $Q_{D R}$ maksimum adsorpsiyon kapasitesini $(\mathrm{mg} / \mathrm{g}), K_{D R}$ DR sabitini $\left(\mathrm{mol}^{2} / \mathrm{J}^{2}\right)$ ve $\varepsilon$ ise Polanyi potansiyelini $(\mathrm{J} / \mathrm{mol})$ ifade etmektedir.

Polanyi potansiyeli Eşitlik (5) kullanılarak hesaplanmaktadır.

$\varepsilon=R T \ln \left(1+\frac{1}{C_{e}}\right)$

Eşitlik (5)'te; $R$ gaz sabitini (J/mol K), $T$ çözelti sıcaklığını $(\mathrm{K}), C_{e}$ ise çözeltideki denge RuBisCO derişimini (mg/L) ifade etmektedir.

Adsorpsiyon serbest enerjisi $E_{f e}$ ise Eşitlik (6) yardımıyla hesaplanmaktadır.

$E_{f e}=\frac{1}{\sqrt{-2 K_{D R}}}$

CB-PHEMA mikrokürelere RuBisCO adsorpsiyonu için belirlenen Langmuir ve Freundlich izoterm verileri Tablo $1^{\prime}$ de özetlendi. $4^{\circ} \mathrm{C}, 22^{\circ} \mathrm{C}$ ve $35^{\circ} \mathrm{C}$ sicaklikta; Freundlich izoterm modeli için elde edilen korelasyon katsayıları, Langmuir izoterm modeli için elde edilen korelasyon katsayılarından daha yüksektir. Bu nedenle, CBHEMA mikroküreler üzerine RuBisCO adsorpsiyonu Freundlich izoterm modeline uygundur. RuBisCO adsorpsiyonu heterojen bağlanma bölgelerinde çok tabakalı olarak gerçekleşmekte ve heterojen yüzey üzerinde adsorpsiyon 1sısı ve ilgisi (afinitesi) eşit dağılmamaktadır. DR izoterminden hesaplanan $\mathrm{E}_{\mathrm{fe}}$ değerleri, $4^{\circ} \mathrm{C}$ için $3,790 \mathrm{~kJ} / \mathrm{mol}$, 
$22^{\circ} \mathrm{C}$ için $3,750 \mathrm{~kJ} / \mathrm{mol}$ ve $35^{\circ} \mathrm{C}$ için $3,900 \mathrm{~kJ} / \mathrm{mol}$ 'dür (Tablo 1 ). $\mathrm{E}_{\mathrm{fe}}$ değerlerinin 8 $\mathrm{kJ} /$ mol'den küçük olması CB-PHEMA mikrokürelere RuBisCO adsorpsiyonunun fiziksel adsorpsiyon olduğunu gösterdi [28].

Tablo 1. CB-PHEMA mikrokürelere RuBisCO adsorpsiyonuna ait izoterm parametreleri.

\begin{tabular}{|c|c|c|c|}
\hline \multicolumn{4}{|c|}{ Langmuir izoterm modeli } \\
\hline Sicaklık (K) & 277 & 295 & 308 \\
\hline$Q_{\text {deneysel }}(\mathrm{mg} / \mathrm{g})$ & 28,79 & 33,59 & 37,54 \\
\hline$Q_{L}(\mathrm{mg} / \mathrm{g})$ & 57,8 & 83,3 & 208,3 \\
\hline$K_{L}(L / m g)$ & 2,403 & 1,690 & 0,530 \\
\hline $\mathbf{R}^{2}$ & 0,9308 & 0,8983 & 0,8034 \\
\hline \multicolumn{4}{|c|}{ Freundlich izoterm modeli } \\
\hline Sicaklık (K) & 277 & 295 & 308 \\
\hline$K_{F}(\mathrm{mg} / \mathrm{g})(\mathrm{L} / \mathrm{mg})^{1 / \mathrm{n}}$ & 54,61 & 71,03 & 83,21 \\
\hline $\mathbf{n}$ & 1,453 & 1,297 & 1,112 \\
\hline $\mathbf{R}^{2}$ & 0,9949 & 0,9896 & 0,9975 \\
\hline \multicolumn{4}{|l|}{ DR izoterm modeli } \\
\hline Sicaklık (K) & 277 & 295 & 308 \\
\hline$Q_{\text {deneysel }}(\mathrm{mg} / \mathrm{g})$ & 28,79 & 33,59 & 37,54 \\
\hline $\mathrm{Q}_{\mathrm{D}-\mathrm{R}}(\mathrm{mg} / \mathrm{g})$ & 34,63 & 43,80 & 49,20 \\
\hline $\mathrm{K}_{\mathrm{D}-\mathrm{R}} \times 10^{8}\left(\mathrm{~mol}^{2} / \mathrm{J}^{2}\right)$ & 3,490 & 3,560 & 3,290 \\
\hline $\mathrm{E}(\mathrm{kJ} / \mathrm{mol})$ & 3,790 & 3,750 & 3,900 \\
\hline $\mathbf{R}^{2}$ & 0,9565 & 0,9707 & 0,9743 \\
\hline
\end{tabular}

Kinetik çalışmalar $4{ }^{\circ} \mathrm{C}, 22^{\circ} \mathrm{C}$ ve $35^{\circ} \mathrm{C}$ sıcaklıkta gerçekleştirldi. Sıcaklığın $4^{\circ} \mathrm{C}$ 'den $35^{\circ} \mathrm{C}$ 'ye yükselmesi ile CB-PHEMA mikrokürelere adsoplanan RuBisCO miktarının artması, adsorpsiyonun endotermik olduğunu gösterdi. $0,8 \mathrm{mg} / \mathrm{mL}$ başlangıç RuBisCO derişiminde üç faklı sıcaklıkta elde edilen adsorpsiyon verilerinin yalancı-birinci derece [29] ve yalanc1-ikinci derece [30] kinetik modele uygunluğu araştırıldı. Kinetik modellere ait denklemler sırasıyla Eşitlik (7) ve Eşitlik (8)'deki gibidir.

Yalanc1 birinci derece $\log \left(q_{e}-q_{t}\right)=\log q_{e}-\frac{k_{1} t}{2.303}$

Yalanc1 ikinci derece $\quad \frac{t}{q_{t}}=\frac{1}{k_{2} q_{e}^{2}}+\frac{1}{q_{e}} t$

Eşitlik (7) ve Eşitlik (8)' de; $k_{1}(1 / \mathrm{dk})$ ve $k_{2}((\mathrm{~g} / \mathrm{mg}) / \mathrm{dk})$ sırasılyla yalancı-birinci derece ve yalanc1-ikinci derece adsorpsiyon hız sabitini, $t$ zamanı $(\mathrm{dk}), q_{e}$ ve $q_{t}$ ise sirasiyla dengede ve herhangi bir $t(\mathrm{dk})$ anında adsorplanan RuBisCO miktarını $(\mathrm{mg} / \mathrm{g})$ ifade etmektedir. Eşitlik (7) ve Eşitlik (8) kullanılarak hesaplanan kinetik parametreler Tablo 2'de gösterildi. Yalanc1-ikinci derece model için elde edilen korelasyon katsayısı değerlerinin daha büyük olması $(\geq 0.9989)$ ve deneysel olarak elde edilen $q_{e}$ (deneysel) değerlerinin çalışılan tüm sıcaklıklarda hesaplanan $q_{e}$ değerlerine yakın olması, RuBisCO adsorpsiyon prosesinin yalanc1-ikinci derece kinetik modele uygun olduğunu gösterdi. 
Tablo 2. CB-PHEMA mikrokürelere RuBisCO adsorpsiyonuna ait kinetik parametreler.

\begin{tabular}{|c|c|c|c|}
\hline \multicolumn{4}{|c|}{ Yalancı-birinci derece kinetik model } \\
\hline Sicaklık (K) & 277 & 295 & 308 \\
\hline$q_{e \text { deneysel }}(\mathrm{mg} / \mathrm{g})$ & 25,24 & 29,15 & 32,36 \\
\hline$q_{e}(\mathrm{mg} / \mathrm{g})$ & 7,948 & 9,867 & 11,860 \\
\hline$k_{1}(1 / \mathrm{dk})$ & 0,0053 & 0,0032 & 0,0035 \\
\hline $\mathbf{R}^{2}$ & 0,9195 & 0,8771 & 0,9161 \\
\hline \multicolumn{4}{|c|}{ Yalancı-ikinci derece kinetik model } \\
\hline Sicaklık (K) & 277 & 286 & 298 \\
\hline$q_{e \text { deneysel }}(\mathrm{mg} / \mathrm{g})$ & 25,24 & 29,15 & 32,36 \\
\hline$q_{e}(\mathrm{mg} / \mathrm{g})$ & 25,32 & 29,30 & 32,60 \\
\hline$k_{2} \times 10^{3}((g / m g) / d k)$ & 2,91 & 1,67 & 1,37 \\
\hline $\mathbf{R}^{2}$ & 0,9998 & 0,9999 & 0,9989 \\
\hline
\end{tabular}

CB-PHEMA mikrokürelere RuBisCO adsorpsiyonuna ilişkin termodinamik parametreler; Gibbs serbest enerji değişimi $\left(\Delta G^{\circ}\right)$, entalpi değişimi $\left(\Delta H^{\circ}\right)$ ve entropi değişimi $\left(\Delta S^{\circ}\right)$ Van’t Hoff eşitliği kullanılarak hesaplandı.

$\ln K=\frac{\Delta S^{\circ}}{R}-\frac{\Delta H^{\circ}}{R}\left(\frac{1}{T}\right)$

$\Delta G^{\circ}=\Delta H^{\circ}-T \Delta S^{\circ}$

Gibbs serbest enerji değişimi $\left(\Delta G^{\circ}\right)$ değerleri; $4^{\circ} \mathrm{C}, 22^{\circ} \mathrm{C}$ ve $35^{\circ} \mathrm{C}$ sıcaklık için sırasıyla $-9,22 \mathrm{kj} / \mathrm{mol},-10,44 \mathrm{~kJ} / \mathrm{mol}$ ve $-11,33 \mathrm{~kJ} / \mathrm{mol}$ olarak belirlendi. Negatif $\Delta G^{\circ}$ değerleri CB-PHEMA mikrokürelere RuBisCO adsorpsiyonunun kendiliğinden gerçekleştiğini gösterdi. Ayrıca, $\Delta G^{\circ}$ değerlerinin artan sıcaklık ile azalması RuBisCO adsorpsiyonunun yüksek sıcaklıklarda daha istemli olduğunu kanıtladı. Entalpi değişimi $\left(\Delta H^{\circ}\right)+9,661 \mathrm{~kJ} / \mathrm{mol}$ olarak hesapland1 ve RubisCO adsorpsiyonunun endotermik doğasını kanıtladı. Entropi değişimi $\left(\Delta S^{\circ}\right),+68,14 \mathrm{~J} / \mathrm{mol} . \mathrm{K}, \mathrm{RuBisCO}$ adsorpsiyon prosesi sırasında sistemin düzensizliğinin arttığını gösterdi.

\subsection{CB-PHEMA mikrokürelerin tekrar kullanımı}

CB-PHEMA mikroküreler RuBisCO adsorpsiyonunda 6 kez tekrar kullanıldı. Tekrar kullanım sırasında; CB-PHEMA mikrokürelere adsorplanan RuBisCO miktarı sırasıyla 15,$33 ; 15,28 ; 15,30 ; 15,32 ; 15,30$ ve $15,29 \mathrm{mg} / \mathrm{g}$ olarak belirlendi. Desorpsiyon ajan1 olarak 1M etilen glikol çözeltisi kullanıldı. Elde edilen sonuçlara göre; CB-PHEMA mikroküler RuBisCO adsorpsiyon kapasitesinde belirgin bir azalma olmaksin tekrar tekrar kullanılabilmektedir.

\subsection{Ispanak protein ekstraktından $\mathrm{RuBis} C \mathrm{O}$ adsorpsiyonu}

CB-PHEMA mikroküreler ile RuBisCO adsorpsiyonu SDS-PAGE analizleri ile takip edildi. $\mathrm{Bu}$ amaçla; saf RuBisCO içeren çözeltiler $(1 \mathrm{mg} / \mathrm{mL}, 3 \mathrm{~mL}, \mathrm{pH} 6,0)$ ve ispanak protein ekstraktı (3 mL, pH 6,0) mikroküreler (CB-PHEMA ve/veya PHEMA) ile muamele edildi. Adsorpsiyon öncesi ve sonrası ortamdan alınan protein örnekleri SDS- 
PAGE ile analiz edildi. Şekil 8 (a)'da; adsorpsiyon öncesi (1) ve adsorpsiyon sonras1 $(2,3,4)$ saf RuBisCO çözeltilerinden alınan protein örneklerinin SDS-PAGE analizi ile elde edilen protein bantları görülmektedir. Adsorpsiyon çalışmaları; $0,25 \mathrm{~g}, 0,5 \mathrm{~g}$ ve $1,0 \mathrm{~g}$ CB-PHEMA mikroküre kullanılarak gerçekleştirildi. SDS-PAGE jelde $55 \mathrm{kDa}$ ve $15 \mathrm{kDa}$ molekül ağırlığında olmak üzere iki bant gözlendi. RuBisCO'nun bitki yapraklarındaki toplam çözünür proteinlerin \%50 sini oluşturduğu tahmin edilmektedir [31]. RuBisCO kloroplastların stromasında bulunur ve bitki türüne göre kloroplast proteinlerinin \%15-50 sini oluşturur [32]. Yüksek bitkiler, algler ve siyanobakterilerde RuBisCO iki farklı alt birimin sekiz adet kopyasından oluşur (Form I RuBisCO). Büyük alt birim $55 \mathrm{kDa}$ ve küçük alt birim ise $15 \mathrm{kDa}$ molekül ağırlığına sahiptir [33]. CB-PHEMA mikroküreler ile saf RuBisCO çözeltilerinden adsorpsiyon sonrasında protein bantlarının yoğunluğunun azaldığı ve bant yoğunluklarındaki azalışın, artan CB-PHEMA miktarı ile arttığı belirlendi.

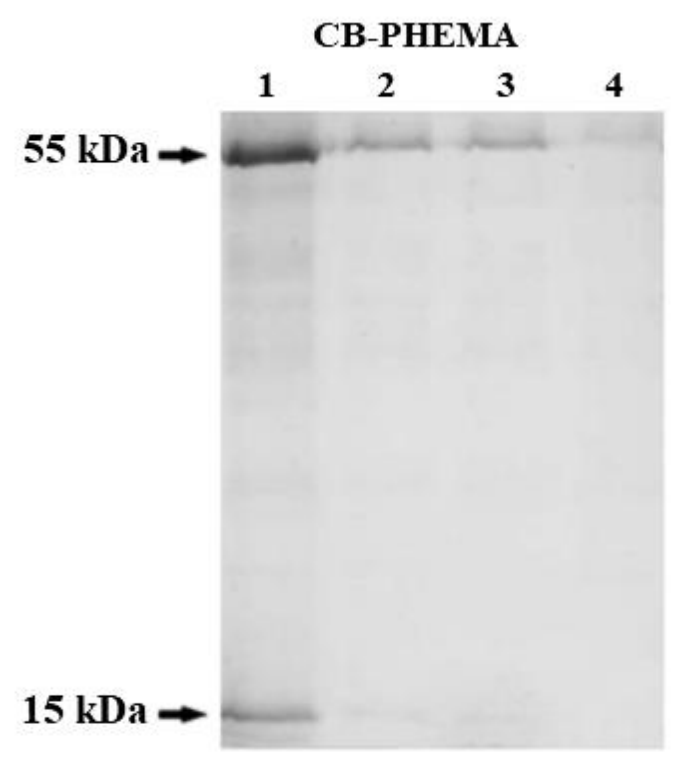

(a) Saf RubisCO

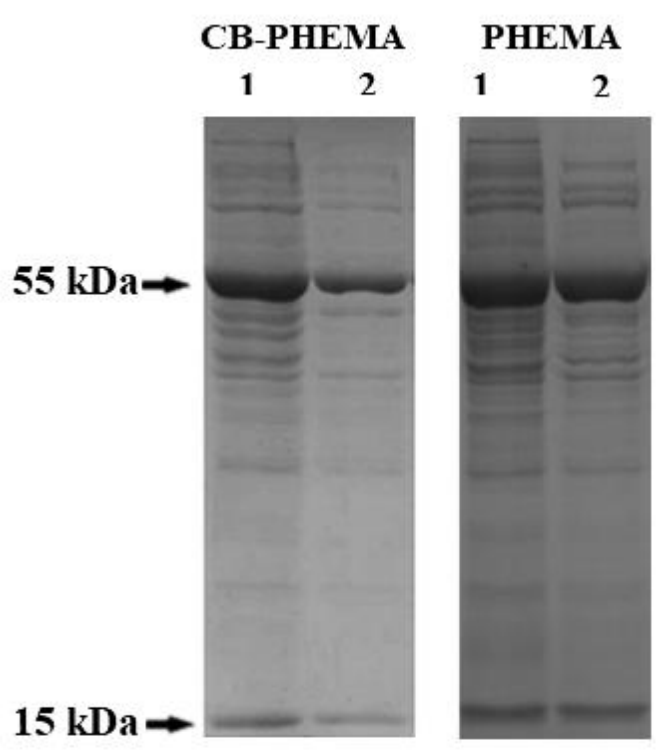

(b) Ispanak protein ekstraktı

Şekil 8. Saf RuBisCO çözeltilerine ve 1spanak protein ekstraktına ait SDS-PAGE jeller: (a) adsorpsiyon öncesi (1) ve $0,25 \mathrm{~g}(2), 0,5 \mathrm{~g}$ (3) ve $1,0 \mathrm{~g}$ (4) CB-HEMA mikroküre ile adsorpsiyon sonrası RuBisCO çözeltisinden alınan protein örneklerine (b) adsorpsiyon öncesi (1) ve 0,5 g (2) CB-HEMA/PHEMA mikroküre ile adsorpsiyon sonrası 1spanak protein ekstraktından alınan protein örneklerine aittir.

Ispanak protein ekstraktı ise; 0,5 g CB-PHEMA ve 0,5 g PHEMA mikroküre ile muamele edildi. Adsorpsiyon öncesi ve sonrası 1spanak protein ekstraktı örnekleri SDSPAGE jelde yürütüldü. Şekil 8 (b)'de adsorpsiyon öncesi (1) ve adsorpsiyon sonrası (2) protein ekstraktından alınan protein örneklerinin SDS-PAGE jel görüntüleri verildi. Adsorpsiyon öncesi ispanak protein ekstraktına ait SDS-PAGE jeller incelendiğinde (Sıra 1); ekstrakt içerisinde farklı molekül ağırlığına sahip çok sayıda proteinin olduğu, ancak $55 \mathrm{kDa}$ ve $15 \mathrm{kDa}$ molekül ağırlığındaki protein bant yoğunluklarının RuBisCO varlığı nedeniyle oldukça yüksek olduğu görüldü. CB-PHEMA mikroküreler ile adsorpsiyon sonrasında (Sıra 2), $55 \mathrm{kDa}$ ve $15 \mathrm{kDa}$ molekül ağırlığındaki bant yoğunluklarının dikkate değer ölçüde azaldığı, ancak PHEMA mikroküreler ile muamele edilen protein örneklerine (adsorpsiyon sonrası) ait SDS-PAGE jelde (Sıra 2); aynı molekül ağırlıklarındaki protein bant yoğunluklarında belirgin bir azalmanın 
olmadığı tespit edildi. Bu sonuç, $\mathrm{CB}$ molekülleri ile RuBisCO arasında spesifik bir etkileşim olduğunu açık bir şekilde kanıtladı. Hayvansal ve bitkisel hücrelerde biyobelirteç olarak kullanılan reseptör ve/veya sinyal/düzenleyici proteinler genellikle nispeten düşük bollukta bulunmakta ve bu proteinler yüksek bollukta bulunan proteinler tarafından maskelenmektedir [10, 34, 35]. Bitki proteom çalışmalarında, fotosentetik bitki dokularında biyobelirteç olarak kullanılabilecek fonksiyonel proteinlerin saptanmasında RuBisCO çok önemli bir sınırlayıcı proteindir [10]. Bu çalışmada elde edilen sonuçlar, fotosentetik bitki dokularında yüksek bollukta bulunan RuBisCO proteininin uzaklaştırılmasında kullanılabilecek alternatif bir yöntemin geliştirilebilmesi için ümit vadetmektedir. Öte yandan, CB-PHEMA ile muamale edilmiş ispanak proteinlerinin yürütüldüğ̈̈ jelde, adsorpsiyon öncesi gözlemlenen çok sayıda farklı proteinin bandının da yoğunluklarının azaldığı tespit edilmiştir. Bu sonuç, CB-PHEMA mikrokürelerin RuBisCO yanında başka proteinleride adsorplamasından kaynaklanmaktadır. İmmunafinite tekniğinde de; ligand olarak kullanılan antikorların yüksek seçiciliklerine rağmen, hedef protein yanında çok sayıda protein immun afinite kolonlarına adsorplanmaktadır. İnsan albümin antikorları içeren immumafinite kolon kullanılarak insan plazmasından albumin uzaklaştırıldığında, albumin ile birlikte 32 adet farklı proteinin kolona adsorplandığı belirlenmiştir [36]. Aynı çalışmada, CB boya ligandı içeren ticari bir kolon ile insan plazmasından albumin uzaklaştırılmış ve albumin ile birlikte 60 adet farklı proteinin kolona adsorplandığ 1 tespit edilmiştir. Bu nedenle ileride yapılacak çalışmalarda; CB-PHEMA mikroküreler ile RuBisCO adsorpsiyonu sırasında ıspanak protein ekstraktından RuBisCO ile birlikte adsorplanan proteinlerin, 2D jel elektroforezi ve LC/MS/MS çalışmaları ile belirlenmesi uygun olacaktır.

\section{Kaynaklar}

[1] Cánovas, F.M., Dumas-Gaudot, E., Recorbet, G., Jorrin, J., Mock, H.P., Rossingnol, M., Plant proteome analysis, Proteomics, 4, 285-298, (2004).

[2] Rabilloud, T., Solubilization of proteins for electrophoretic analyses, Electrophoresis, 17,813-829. 1996.

[3] Rose, J.K., Bashir, S., Giovannoni, J.J., Jahn, M.M., Saravanan, R.S., Tackling the plant proteome: practical approaches, hurdles and experimental tools Plant Journal, 39,715-733, (2004).

[4] des Francs, C.C., Thiellement, H., de Vienne, D., Analysis of leaf proteins by two-dimensional gel electrophoresis: protease action as exemplified by Ribulose bisphosphate carboxylase/oxygenase degradation and procedure to avoid proteolysis during extraction, Plant Physiology, 78,178-182, (1985).

[5] Gegenheimer, P., Preparation of extracts from plants, Methods in Enzymology,182,174-193, (1990).

[6] Wilkins, M.R., Gasteiger, E., Sanchez, J.C., Bairoch, A., Hochstrasser, D.F. Twodimensional gel electrophoresis for proteome projects: The effects of protein hydrophobicity and copy number, Electrophoresis, 19,1501- 1505, (1998).

[7] Corthals, G.L., Wasinger, V.C., Hochstrasser, D.F., Sanchez, J.C., The dynamic range of protein expression: a challenge for proteomic research, Electrophoresis, 21,1104-1115, (2000).

[8] Freeby, S, Berkelman, T, Paulus, A, Liu, N, Wehr, T, Academia, K, Walker, J. 2D-analysis of leaf protein samples treated with proteominer beads under denaturing and non-denaturing conditions. https://www.biorad.com/webroot/web/pdf/lsr/literature/Bulletin_6441.pdf (12.01.2021) 
[9] Kim, S.T., Cho, K.S., Jang, Y.S., Kang, K.Y., Two-dimensional electrophoretic analysis of rice proteins by polyethylene glycol fractionation for protein arrays, Electrophoresis, 22, 2103-2109, (2001).

[10] Xi, J.H., Wang, X., Li, S.Y., Zhou, X., Yue, L., Fan, J., Hao, D.Y., Polyethylene glycol fractionation improved detection of low-abundant proteins by twodimensional electrophoresis analysis of plant proteome, Phytochemistry, 67, 2341-2348, (2006).

[11] Cellar, N.A., Kuppannan, K., Langhorst, M.L., Ni, W., Xu, P., Young, S.A., Cross species applicability of abundant protein depletion columns for ribulose-1,5bisphosphatecarboxylase/oxygenase, Journal of Chromatography B: Analytical Technologies in the Biomedical and Life Sciences, 861, 29-39, (2008).

[12] Denizli, A., and Piskin, E., Dye-ligand affinity systems, Journal of Biochemical and Biophysical Methods, 49, 391-416, (2001).

[13] Stellwagen, E., Chromatography on immobilised reactive dyes, Methods in Enzymology, 182, 343-357, (1990).

[14] Roschlau, P., Hess, B., Affinity chromatography of yeast pyruvatekinase with Cibacron blue bound to Sephadex G-200, Hoppe-Seyler's Zeitschrift fur physiologische Chemie, 353,441-443, (1972).

[15] Lowe, C.R., Gald, M., Larsson, P.O., Ohlson, S., Small, D.A.P., Atkinson, T., High performance liquid affinity chromatography of proteins on Cibacron Blue F3GA bonded silica, Journal of Chromatography, 215-303, (1981).

[16] Lowe, C.R., Hans, M., Spibey, N., Drabble, W.T., The purification of inosine-5monohosphate dehydrogenase from Escherichia coli by affinity chromatography on immobilized Procion dyes, Analytical Biochemistry, 104, 23-28, (1980).

[17] Dean, P.D.G., Watson, D.H., Protein purification using immobilised triazine dyes, Journal of Chromatography, 165: 310-319, (1969).

[18] Bollin, E., Vastola, K., Olezsak, P., Sulkowski, E., The interaction of mamallian interferons with immobilized Cibacron Blue F3GA: modulation of binding strength, Preparative Biochemistry, 8, 259-264, (1978).

[19] Biellman, J.F., Samma, J.P., Branden, C.I., Eklund H., X-ray studies of the binding of Cibacron Blue F3GA to liver alcohol dehydrogenase, European Journal of Biochemistry, 102-107, (1979).

[20] Travis, J., Pannell, R., Selective removal of albumin from plasma by affinity chromatography, Clinica Chimica Acta, 49, 49-52, (1973).

[21] Travis, J., Brown, J., Tewksbury, D., Johnson, D., Pannell, R., Isolation of albumin from whole human plasma and fractionation of albumin-depleted plasma, Biochemical Journal,157, 301-306, (1976).

[22] Odabaş1, M., Denizli, A., Cibacron Blue F3GA incorporated magnetic poly(2hydroxyethyl methacrylate) beads for lysozyme adsorption, Journal of Applied Polymer Science, 93, 719-725, (2004).

[23] Jankowski, W.J., Ansen, W.H., Sulkowski, E., Carter, W.A., Binding of human interferons to immobolized Cibacron Blue F3GA: The nature of molecular interaction. Biochemistry, 15, 5182-5187, (1976).

[24] Nynäs, A.L., White proteins from green leaves in food applications. A literature study. Alnarp: Sveriges lantbruksuniversitet. (Introductory paper at the Faculty of Landscape Architecture, Horticulture and Crop Production Science, (2018).

[25] Langmuir, I., The constitution and fundamental properties of solids and liquids. Part 1. Solids, Journal of the American Chemical Society, 38, 2221 - 2295, (1916). 
[26] Freundlich, H.M.F., Over the Adsorption in Solution, Journal of Physical Chemistry, 57, 385-471, (1906).

[27] Dubinin, M.M., Radushkevich, L.V., The equation of the characteristic curve of activated charcoal, Proceedings of the Academy of Sciences of the USSR. Physical Chemistry Section, 55,331-337, (1947).

[28] Unlü, N., Ersoz M., Adsorption characteristics of heavy metal ions onto a low cost biopolymer sorbent from aqueous solutions, Journal of Hazardous Materials, 136, 272-280, (2006).

[29] Lagergren, S., Zur theorie der sogenannten Adsorption gel oster stoffe, Kungliga Svenska Vetenskapsakademiens, Handlingar, 25,4, 1-39, (1898).

[30] Ho, Y.S., McKay, G., Pseudo-second-order model for sorption processes, Process Biochemistry, 34, 451-465, (1999).

[31] Ellis, R.J., Most abundant protein in the World, Trends in Biochemical Sciences, 4, 241-244, (1979).

[32] Vapaavuori, E.M., Correlation of activity and amount of ribulose 1,5bisphosphate carboxylase with chloroplast stroma crystals in water-stressed willow leaves, Journal of Experimental Botany, 37, 174, 189-198, (1986).

[33] Maeda, N., Kitano, K., Fukui, T., Ezaki, S., Atomi, H., Miki, K., Tadayuki Imanaka, T., Ribulose bisphosphate carboxylase/oxygenase from the hyperthermophilic archaeon pyrococcus kodakaraensis kod1 is composed solely of large subunits and forms a pentagonal structure, Journal of Molecular Biology, 293, 57-66, (1999).

[34] Yang, H.,Wang, G., Zhang, T., Beattie, J.H., Zhou S. Establishing an optimized method for the separation of low and high abundance blood plasma proteins. Analytical Chemistry at Peer Journal. DOI: 10.7717/peerj-achem.6, (2020).

[35] Gupta R. High abundance proteins: Proteomer's thorns in the flesh? Journal of Proteomics \& Bioinformatics. 10, 7, 1000e35,(2017).

[36] Zolotarjova, N., Nicol, G., Martosella, J., Yang, L-S., Zhang, K., Boyes, B., Evaluation of serum albumin depletion methods for proteomic analysis, HPLC, Nice, France, (2003). 